\title{
Seed hydropriming in upland rice improves germination and seed vigor and has no effects on crop cycle and grain yield
}

\author{
Vitor Henrique Vaz Mondo', Adriano Stephan Nascente*1, Péricles de Carvalho Ferreira Neves ${ }^{1}$, \\ James Emile Taillebois ${ }^{2}$, Flávio Henrique Sousa Oliveira ${ }^{3}$
}

\author{
${ }^{1}$ Embrapa Arroz e Fejão, Rodovia GO-462, Km 12, Fazenda Capivara, Zona Rural Caixa Postal: 179 CEP: \\ 75375-000 - Santo Antônio de Goiás - GO, Brasil
}

${ }^{2}$ CIRAD - Centre de CoopérationInternationaleenRechercheAgronomique pour le Développement, Montpellier, France

3Federal University of Goiás, Goiânia, Goiás, Brazil

*Corresponding author: adriano.nascente@embrapa.br

\begin{abstract}
Improved seed priming techniques can reduce time between seed sowing and seedling emergence, resulting in rapid and uniform seedlings emergence, high seed vigor, better and uniform stand establishment, better allometric and better yields in many field crops. The objective of this research was to understand the effects of hydropriming on rice seed physiological potential and on crop performance for upland rice systems. Therefore, the laboratory and field trials were carried out. Initially, two seed lots from two upland rice varieties were used to create imbibition curves, required to establish the priming protocols. The priming protocols (zero, as reference, 16 and $22 \mathrm{~h}$ of priming duration) were applied and their effects on seed physiological potential were evaluated. One seed lot of primed seeds for each variety was used in field trials, carried out in two consecutive growing seasons (2013/14 and 2014/15) in a randomized complete block design, split plot scheme, with six replications. The effects of priming seeds were uniquely associated with their physiological potential, including germination and vigor, which is expected to bring benefits to the faster establishment and uniform stands in the field. However, those benefits did not extend beyond the early stages of crop development and were not observed on flowering and grain yield.
\end{abstract}

Keywords: flowering; grain yield; Oryza sativa L.; seed enhancements; seed quality.

Abbreviations: G_germination; GDD_growing-degree-days; SL_seedling length; SE_seedling emergence.

\section{Introduction}

The technology of seed priming is defined as a pre-sowing treatment that allows seeds to imbibe water and proceed to the first stages of germination, but prevents radicle protrusion through the seed coat (Heydecker et al., 1973; Bewley and Black, 1982; Chen and Sung, 2001; Farooq et., 2009; Silva et al., 2015). The concept seems viable since most seed embryos are desiccation-tolerant up to a certain developmental stage, and the seed advancement in germination process during priming can be arrested by drying without any damage (Capron et al., 2000; Marcos-Filho, 2005).

The technique contemplates a controlled hydration of the seeds to a point, where it primarily reduces the lag time of imbibitions (Brocklehurst and Dearman 2008). Also, it starts the build-up of germination enhancing metabolites (Chen and Sung, 2001; Basra et al., 2005; Farooq et al., 2007; Sliwinska et al., 2009; Varier et al., 2010; Hussain et al. 2015), promotes metabolic repair during imbibition, as early DNA replication and greater ATP availability (Bray et al. 1989; Ashraf and Bray, 1993; Chen and Arora, 2013); promotes osmotic adjustments (Bradford 1986) and membrane reorganization through restoring their originalstructures, reducing leakage of metabolites (Fujikura and Karssen,
1995). It can also induce or enhance the level and activity of enzymes of antioxidant defense (Roqueiro et al., 2012), preventing lipid peroxidation during germination (Azooz, 2009).

There are several methods for priming controlled hydration. Among the most studied are hydropriming (Farooq et al., 2006c), osmoconditioning (Rehman et al., 2015), osmohardening (Farooq et al., 2006a,b,d), hardening (Farooq et al., 2004), hormonal priming (Basra et al., 2005; Ashraf and Foolad, 2005), soaking prior to sowing (Harris et al., 2002), priming with nutrients (Jafar et al., 2012; Khaliq et al., 2015;Rehman et al,. 2015) and also with chemical molecules (Mohanasarida and Mathew, 2005b).

Improved seed priming techniques can reduce time between seed sowing and seedling emergence, resulting in rapid and uniform seedlings emergence, high seed vigor, better and uniform stand establishment, better allometric and better yields in several vegetable and flower species as well as in many field crops (Capron et al., 2000; Ashraf and Foolad, 2005; Basra et al. 2005; Farooq et al 2005; Subedi and Ma, 2005; Hussain et al. 2006; Abdulrahmani et al., 2007; Arif et al., 2008; Farooq et al. 2008a; Farooq et al. 2008b; Foti et al., 2008; Ghassemi-Golezani, 2008; Gomes- 
Junior, 2009; Bajehbaj, 2010; Rehman et al. 2011; Jafar et al., 2012; Mondo et al., 2013; Rehamn et al,. 2014; Rehman et al,. 2015; Rehman et al., 2015). In addition to crop establishment improvements, other benefits are also recognized, such as better drought tolerance, low temperatures, salinity tolerance, better weed competition, early flowering, reduced time to maturity and higher grain yield (Valdes et al., 1985; Bradford, 1986; Wieber and Muhyaddin, 1987; Pill and Finch-Savage, 1988; Frett and Pill, 1989; Kaur et al., 2005; Rehman et al., 2014).

Priming techniques are being studied extensively in the last decades for irrigated rice production systems, with the purpose of enhancing seedling vigor (Lee et al., 1998; Harris et al., 2002; Basra et al., 2002; Basra et al., 2003; Basra et al., 2004; Farooq et al, 2004; Basra et al., 2005; Farooq et al, 2005; Mohanasarida and Mathew, 2005; Farooq et al., 2006a; Farooq et al., 2006b; Farooq et al., 2006e; Farooq et al., 2008a; Khaliq et al., 2015). A promising strategy that may permit direct field sowing is the use of primed seeds, providing enhancement of the physiological performance of seeds and helping to resolve the challenge of poor stand establishment (Bradford et al., 1990; Demir and Okcu, 2004; Farooq et al., 2011).

Rice is included in the diet of half of the world's population (Prasad, 2011; Nascente et al., 2013). Besides, the rice demand is increasing to an expected 116 million of metric tons by the year 2035 in relation to the world rice production in 2010 (GRiSP, 2013). Therefore, there is a need to develop technologies to result in higher rice grain yield (Akhter et al., 2007; Qin et al., 2013). The upland system for rice production is considered as one of the most sustainable alternatives, in which impact of seed priming might have great relevance. However, studies relating the effects of seed priming in upland rice varieties are very rare. In this scenario, the objective of this research was to understand the effects of hydropriming on seed physiological potential and on crop performance for upland rice systems.

\section{Results and Discussion}

\section{Effects of hydropriming on seed physiological potential}

The time required for the seeds of each variety to achieve high and constant water contents (Fig 1) was identified. For both, 'BRSGO Serra Dourada' and 'BRS Esmeralda', the water content was stabilized around $30 \%$, and the time required to reach that level, around $16 \mathrm{~h}$. It is worth to note that the time required for radicle protrusion for both cultivars was around $30 \mathrm{~h}$. These two points are the references for the priming concept, and the closer to radicle protrusion; the embryos become less tolerant to desiccation. Based on those results, three treatments were defined: zero, as reference, 16 , 22 and $28 \mathrm{~h}$ of imbibition period, or priming duration. Those results and treatments definition agree with the findings of Harris et al. (2002) and WARDA (2002), where treatments for evaluating priming protocols varied between 12 and $24 \mathrm{~h}$. We added the $28 \mathrm{~h}$ treatment, closer to the time when occurs the radicle protrusion.

After primed, seeds were dried until $13 \%$ of water content, stored, and submitted to physiological potential evaluations, through germination and vigor tests (Fig 2 and Fig 3). The seeds reached a level of $25 \%$ of water content with $16 \mathrm{~h}$ and remained at around $30 \%$ after a period of $22 \mathrm{~h}$, indicating that the soaking process was slower than the preliminary studies, but has stabilized in the range of $30 \%$ for both varieties (Fig $2 \mathrm{~A}$ and $3 \mathrm{~A})$.
Comparatively to untreated seeds, the seed lot physiological potential is expected to be enhanced by applying the primer technique (Capron et al., 2000). Usualy, the references for assessing the seed quality are the percent of germination, which translates the potential for a seed lot to produce normal seedlings under controlled temperature, and percent of seedlings emergence, considered as a vigor test, that approximate the results to field conditions. According to McDonald (1999), a successful crop establishment requires high quality of seeds, which emerge promptly under a wide range of field conditions. It is well-known that different varieties and different lots of the same variety could have different responses for priming treatments, found by Mondo et al. (2013) for Lactuta sativa. However, Pame et al. (2015) observed a generally positive effect of priming, irrespective of genotype and seed attributes. In this experiment, regarding to germination (Figs $2 \mathrm{~B}$ and $3 \mathrm{~B}$ ), the $16 \mathrm{~h}$ treatment had the higher results for both varieties and seed lots. For seedlings emergence, 'BRSGO Serra Dourada' Lot 1 (Fig 2D) obtained the peak performance after $16 \mathrm{~h}$ treatment, while Lot 2 showed stabilization after $22 \mathrm{~h}$, that was its best performance. For 'BRS Esmeralda', the seedlings emergence (Fig 3D) performed similarly to germination results, confirming $16 \mathrm{~h}$ as the most appropriate period for priming of rice seeds. Those results show that the process of seed priming is variable between lots and even among cultivars.

The seedlings length and emergence speed index, (Figs 2C and 2E for 'BRSGO Serra Dourada', and Figs 3C and 3E for 'BRS Esmeralda'), in general, showed similar tendencies compared to germination and seedling emergence. For seedling length, both Lot 1 and 2 of 'BRSGO Serra Dourada' showed better results after 22h. For 'BRS Esmeralda', treatment of $16 \mathrm{~h}$ was clearly the better one. For emergence speed index, related to seedling emergence, the results for 'BRSGO Serra Dourada' corroborated the the seedling emergence results, and the best priming duration was treatment $16 \mathrm{~h}$ for Lot 1 and $28 \mathrm{~h}$ for Lot 2. 'BRS Esmeralda' had the same consistency, and the best priming duration was treatment $16 \mathrm{~h}$ for both lots to leverage the physiological potential.

When evaluating the efficiency of priming methods, it is important to use different varieties and different seed lots from each variety to understand the genetic factor on the results, and to analyze the samples by sets of physiological potential tests, as germination and vigor tests, giving consistency to the results. Considering this and analyzing the whole set of results, the range of priming duration for rice seeds is between 16 to $28 \mathrm{~h}$, confirming previous results found by Harris et al. (2002), Singh and Chatterjee (1981) and Farooq et al. (2006e) that tend to $16 \mathrm{~h}$ duration as having more potential as a priming protocol.

The results of germination and seedling emergence showed that, in general, after $16 \mathrm{~h}$, there is a decrease in seed physiological potential, and $22 \mathrm{~h}$ and $28 \mathrm{~h}$ treatments were considered less efficient than $16 \mathrm{~h}$. Thus, the treatment of $16 \mathrm{~h}$ is recommended for the priming of rice seeds, specifically for the cultivars 'BRSGO Serra Dourada' and 'BRS Esmeralda'. Khaliq et al. (2015), Farooq et al. (2006a), Farooq et al. (2006e), Harris et al. (2002) studying priming protocols also found the benefits of priming for rice seed towards improving germination and seed vigor, and reported it as a successful strategy to enhance seed vigor.

Considering the results obtained in this study, to define the priming method, the treatments for field evaluation were chosen to be zero, as a reference, and priming duration of $16 \mathrm{~h}$ and $22 \mathrm{~h}$. 
Table 1. Chemical soil attributes in the experimental area at the layer 0-0.20 $\mathrm{m}$ in the 2013/2014 and 2014/2015 growing seasons. Santo Antônio de Goiás, Brazil.

\begin{tabular}{|c|c|c|c|c|c|c|c|c|c|c|c|c|}
\hline Growing season & $\mathrm{pH}$ & SOM & $\mathrm{K}$ & $\mathrm{Ca}$ & $\mathrm{Mg}$ & $\mathrm{Al}$ & $\mathrm{H}+\mathrm{Al}$ & $\mathrm{P}$ & $\mathrm{Cu}$ & $\mathrm{Fe}$ & $\mathrm{Mn}$ & $\mathrm{Zn}$ \\
\hline & (water) & $\mathrm{g} \mathrm{dm}^{-3}$ & \multicolumn{5}{|c|}{--------- $\mathrm{cmol}_{\mathrm{c}} \mathrm{dm}^{-3}$} & \multicolumn{5}{|c|}{ 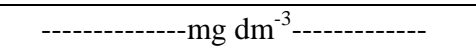 } \\
\hline $2012 / 13$ & 5.4 & 36.8 & 0.15 & 1.6 & 1.0 & 0.2 & 3.0 & 6.1 & 1.1 & 15.3 & 8.9 & 4.5 \\
\hline 2013/14 & 5.5 & 33.3 & 0.34 & 1.3 & 0.7 & 0.1 & 3.8 & 7.5 & 1.1 & 18.0 & 9.4 & 4.2 \\
\hline
\end{tabular}

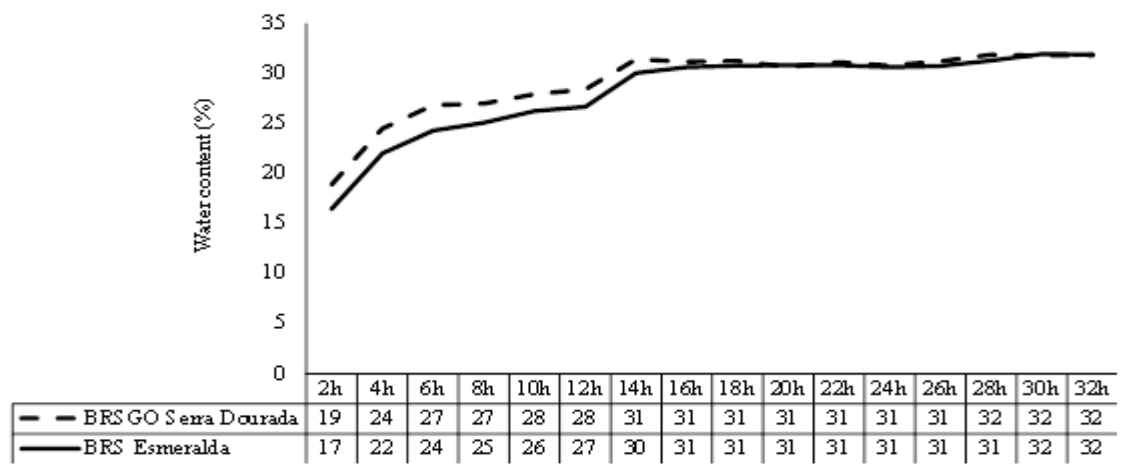

Fig 1. Imbibition curve for seeds of 'BRSGO Serra Dourada' and 'BRS Esmeralda' rice varieties.

Table 2. Growing-degree-days for 'BRSGO Serra Dourada' variety to reach flowering, grain yield and production components as a function of priming duration. Santo Antônio de Goiás, 2013/14 and 2014/15.

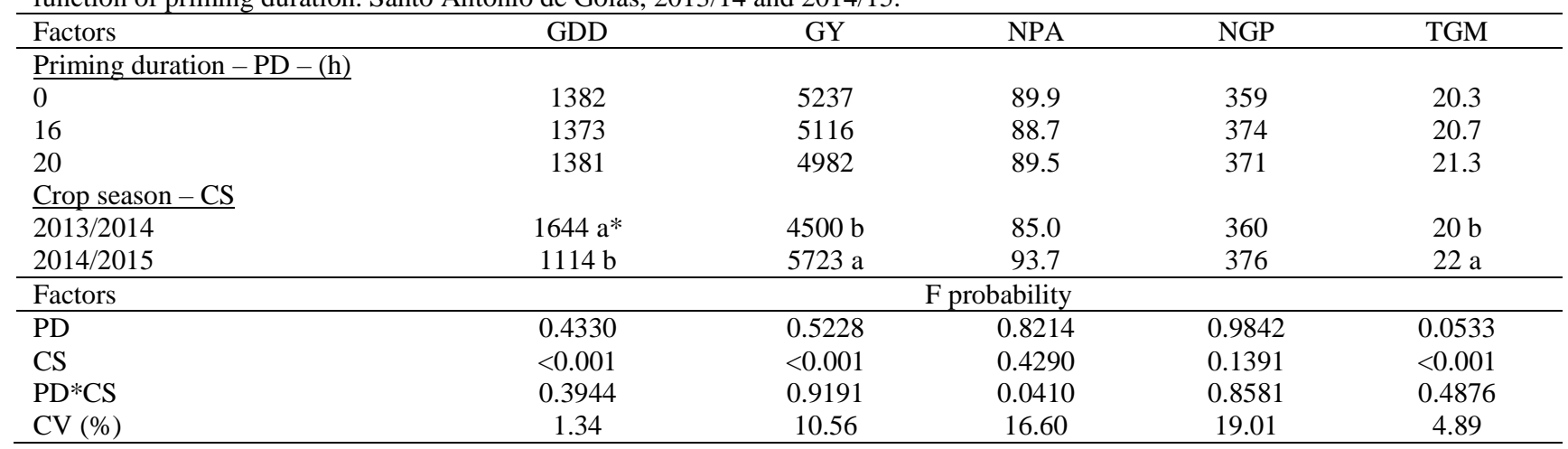

* Means followed by same letter in the column did not differ by Tukey with $\mathrm{p}<0.05$. GDD - Growing-degree-days; GY - Grain yield (kg.ha ${ }^{-1}$ ); NPA - Number of panicles per area $\left(\mathrm{m}^{2}\right)$; NGP - Number of grains per panicle; TGM - Thousand grain mass (g); CV - Coefficient of variance.

Table 3. Growing-degree-days for 'BRS Esmeralda' variety to reach flowering, grain yield and production components as a function of priming duration. Santo Antônio de Goiás, 2013/14 and 2014/15.

\begin{tabular}{|c|c|c|c|c|c|}
\hline Factors & GDD & GY & NPA & NGP & TGM \\
\hline \multicolumn{6}{|c|}{ Priming duration $-\mathrm{PD}-(\mathrm{h})$} \\
\hline 0 & 1385 & 5108 & 99.2 & 321 & 22.1 \\
\hline 16 & 1378 & 5482 & 108.2 & 292 & 22.3 \\
\hline 20 & 1378 & 5282 & 103.4 & 304 & 22.2 \\
\hline \multicolumn{6}{|c|}{ Crop season - CS } \\
\hline $2013 / 2014$ & $1651 \mathrm{a}^{*}$ & $4021 \mathrm{~b}$ & 105.8 & 289 & $20.5 \mathrm{~b}$ \\
\hline $2014 / 2015$ & $1110 \mathrm{~b}$ & $6560 \mathrm{a}$ & 101.4 & 323 & $23.9 \mathrm{a}$ \\
\hline Factors & F Probal & & & & \\
\hline $\mathrm{PD}$ & 0.2913 & 0.4382 & 0.664 & 0.4700 & 0.9028 \\
\hline CS & $<0.001$ & $<0.001$ & 0.2465 & 0.0921 & $<0.001$ \\
\hline $\mathrm{PD} * \mathrm{CS}$ & 0.8379 & 0.4679 & 0.1353 & 0.6317 & 0.8955 \\
\hline $\mathrm{CV}(\%)$ & 0.90 & 13.28 & 10.85 & 19.18 & 5.97 \\
\hline
\end{tabular}

* Means followed by same letter in the column did not differ by Tukey with $\mathrm{p}<0.05$. GDD - Growing-degree-days; GY - Grain yield (kg.ha ${ }^{-1}$ ); NPA - Number of panicles per area $\left(\mathrm{m}^{2}\right)$; NGP - Number of grains per panicle; TGM - Thousand grain mass $(\mathrm{g}) ; \mathrm{CV}$ - Coefficient of variance. 

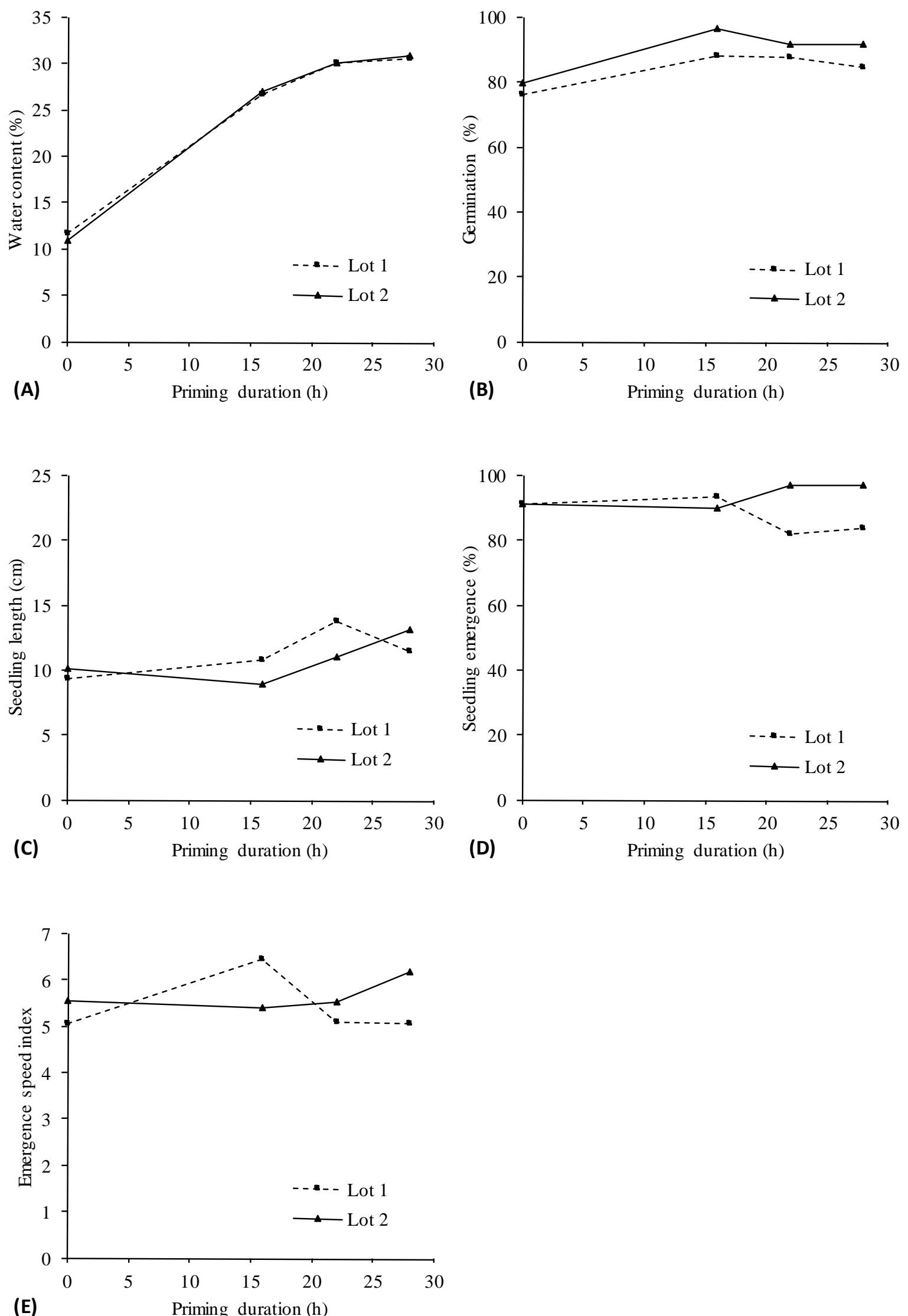

Fig 2. Rice seeds physiological potential for 'BRSGO Serra Dourada' variety after different priming durations. Santo Antônio de Goiás, 2014. 

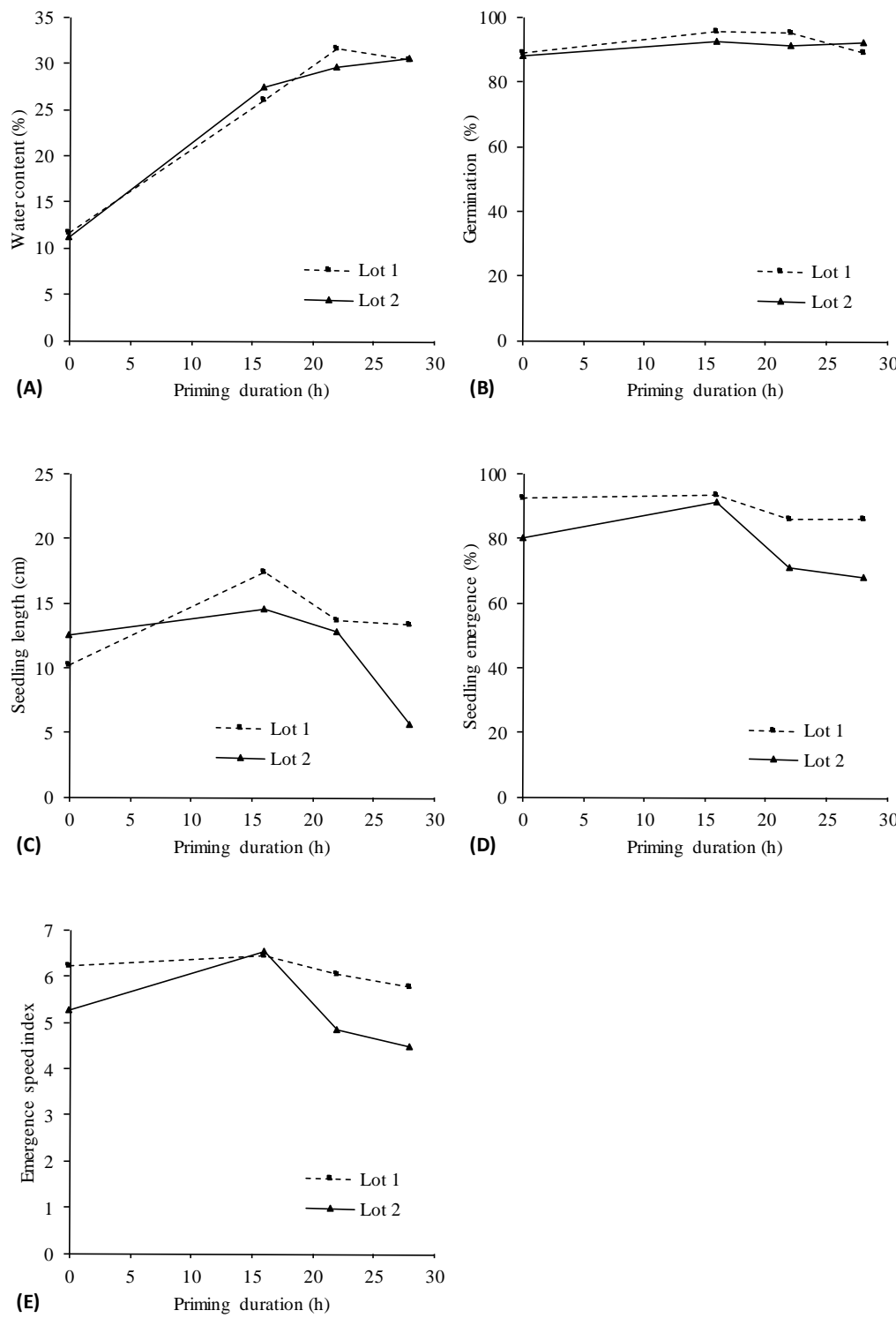

Fig 3. Rice seeds physiological potential for 'BRS Esmeralda' variety after different priming durations. Santo Antônio de Goiás, 2014.

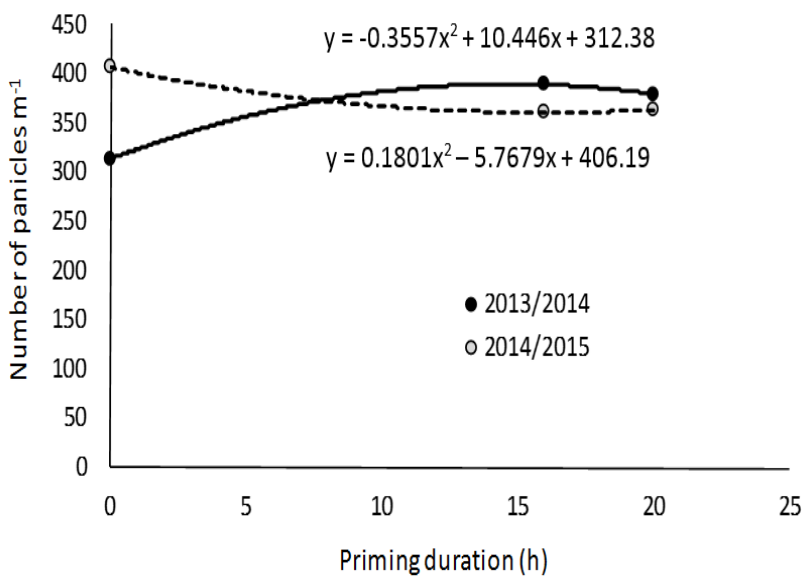

Fig 4. Relation of crop season and priming durations for rice seed of 'BRSGO Serra Dourada' variety and number of panicles per area. Santo Antônio de Goiás, 2013/2014 and 2014/2015. 
Effects of hydropriming on crop performance for upland rice systems

The treatments applied to 'BRSGO Serra Dourada'(Table 2) and 'BRS Esmeralda' (Table 3) did not translate the benefits of seed priming on seed physiological potential to the crop performance in the field. When evaluating the effects of priming technique on the timing of flowering of both varieties, based on the number of growing-degree-days to start flowering, there was no relationship of any treatment with the crop cycle. Those results disagree with Harris et al. (2002), that obtained for on-farm priming an increased rate of germination and emergence by one to three days, resulting in more uniform and vigorous seedling growth. They observed that primed crops emerge faster and completely and additionally produce more vigorous seedlings, flower and mature earlier, and yield better than non-primed crops (Harris et al., 1999).

The early seedling emergence found in this work was not consistent through the reproductive phases, as observed for flowering. However, Farooq et al. (2011) and Fukai (2002) stated that a successful weed competition for rice seeds demands a fast and even germination and good seedling vigor that are characteristics of primed seeds. In the same direction Warda (2002) reported that $12 \mathrm{~h}$ and $24 \mathrm{~h}$ protocols improved crop establishment and, after four weeks from sowing, subsequent growth on leaf area, plant height, root and shoot dry mass in Ghana. Additionally, primed seeds had significantly more tillers, panicles and grains per panicle than non-primed plants. When direct seeding system is used instead of transplanting, crop stand establishment would have become a critical factor affecting subsequent growth, development and yield in rice (Farooq et al., 2011).

Regarding to grain yield and production components, specifically for number of grains per panicle and thousand grain weights, there was no effects of any priming treatment in this study. The number of panicles per area was affected by the interaction of treatments and cropping season, for 'BRSGO Serra Dourada' (Fig4). In 2013/2014, there was a trend of better crop performance and, the $16 \mathrm{~h}$ treatment was the most efficient. Nevertheless, in 2014/2015, the results were the opposite, and non-primed seeds had better performance.

Differing from our results, Singh and Chatterjee (1981), studying priming protocols for three upland rice varieties, improved grain yield by 11 to $14 \%$ over three consecutive years. Furthermore, Mohanasarida and Mathew (2005), tested seed priming with imidacloprid in rice and found increased grain yield by $2.1 \mathrm{t} \mathrm{ha}^{-1}$, when compared to non-primed seeds. Those results were attributed to higher panicle numbers and a higher number of grains per panicle. For other crops, results are diverse in the literature. Arif et al. (2008), working with soybean seeds had faster and improved emergence and higher grain yield of soybean and concluded that seed priming hastens and improves emergence and enhances grain yield for that crop. Rehman et al. (2015), found that osmoprimed maize seeds resulted in improved performance of early planted spring maize, reflected in higher productivity.

However, Subedi and Ma (2005), also working with maize seeds, observed that despite some positive effects of seed priming on seedling vigor and stand establishment, none of the primed seeds showed beneficial effects on grain yield. Giri and Schillinger (2003), working with winter wheat concluded that seed priming has limited practical value for enhancing emergence and grain yield of winter wheat planted deep into summer fallow, observing that no benefit on field emergence or subsequent grain yield in either varieties were obtained. The results from the present study agree with those obtained by Giri and Schillinger (2003) and by Subedi and Ma (2005), sustaining the ones from the present study.

Our data suggests the effect of the cropping season on the means of growing-degree-days, grain yield and thousand grain mass are consistent between varieties. Longer crop cycle in 2013/2014 resulted in lower grain yields and thousand grain mass than in the 2014/2015. Since the crop performance is highly related to climatic conditions, and considering the differences on mean temperatures in each cropping season, those differences can be acceptable.

\section{Materials and methods}

\section{Plant materials}

Seeds from two rice varieties, 'BRSGO Serra Dourada' and 'BRS Esmeralda', two lots each, obtained from Embrapa Rice and Beans, located in Santo Antônio de Goiás, GO, Brazil were used in this study. The seed lots were produced during the summer season of 2012/2013, and had similar characteristics of size and thousand grain mass (data not presented). Two seed lots from each variety were used in the laboratory trials, and one seed lot from each variety was used in the field trials.

\section{Laboratory trials}

The laboratory trials were carried out at the Embrapa Rice and Beans Seed Analysis Laboratory and greenhouses from July to October 2013. Those trials consisted of three phases: determination of the imbibitions curve of the seeds, seed priming, and, seed physiological potential evaluation.

\section{$1^{\text {st }}$ Phase: Determination of imbibition curve}

It aimed at determining the treatments, defined by imbibition duration for the rice seed priming. The imbibition curve was determined for each variety. $30 \mathrm{~g}$ of seeds were placed over three sheets of germination paper towels and covered by two others. The sheets were previously moistened with water ratio equals to 2.5 times the mass of dry paper, following the methodology described by Marcos-Filho (2005). Rolls were formed, identified and positioned in germination chambers at $25^{\circ} \mathrm{C}$ in the dark. The seeds were weighted at every two hours from the beginning until $32 \mathrm{~h}$-period. They were superficially dried on paper towels and weighted again. Using the values of initial weight and the final weight, after imbibition period, it was possible to determine the current water content of each sample. For each variety, one seed lot and two replications were used, totalizing 66 rolls per variety. At evaluation times, the mean values of two replications and the moment of radicle protrusion were recorded. Water content was determined by oven drying two seed samples of $2 \mathrm{~g}$ from each seed lot at $105^{\circ} \mathrm{C} \pm 3^{\circ} \mathrm{C}$ for 24 hours. The samples were weighted, and the seed moisture was expressed in percentage (Brasil, 2009).

\section{$2^{\text {nd }}$ Phase: Seed priming}

Three seed priming protocolos were defined after determining the imbibition curve. The protocols were used as treatments and were composed of zero, as the control, 16, 22 and 28 hours of imbibition periods. For this purpose, $30 \mathrm{~g}$ of each seed lot were placed over three sheets of germination towels and covered by two others. The sheets were previously moistened with water ratio equals to 2.5 times the 
mass of dry paper, following the methodology described by Marcos-Filho (2005). Rolls were formed, identified and positioned in germination chambers at $25{ }^{\circ} \mathrm{C}$ in the dark. At the end of each imbibition period, the seeds were dried until they reached $13 \%$ water content, under controlled conditions, following the method developed by Jianhua and McDonald (1996). Seeds were disposed on a metallic screen inside transparent plastic boxes $(11 \times 11 \times 3 \mathrm{~cm})$ with $40 \mathrm{ml}$ of salt saturated solution $(\mathrm{NaCl})$. The screen prevented the contact of the seeds with the solution. After drying, the seeds were stored under controlled conditions $\left(10{ }^{\circ} \mathrm{C}\right.$ and $40 \%$ of air relative humidity) until the tests of physiological potential were performed. The experimental design was a completely randomized design, with four replications.

\section{$3^{\text {rd }}$ Phase: Seed physiological potential evaluation germination and seed vigor}

Germination $(\boldsymbol{G})$ : Four replications of 50 seeds per lot, were rolled in germination paper towels. For each lot, seeds were uniformly distributed over two sheets of germination paper towels and covered with another sheet. The sheets were previously moistened with water ratio equals to 2.5 times the mass of dry paper. The rolls were vertically placed in germination chambers at $25^{\circ} \mathrm{C}$ in the dark. The percentage of normal seedlings was recorded on the 14th day after sowing (Brasil, 2009).

\section{Seedling length (SL)}

Four replications of 20 seeds per lot were rolled in germination paper towels, similar to the germination test. To avoid contact between seedlings, seeds were positioned with radicle pointing downwards. In order to standardize root growth conditions for all samples, seeds were uniformly distributed along two lines with 10 seeds each, on the upper third of the paper towels. All seedlings were measured by total length $(\mathrm{cm})$ seven days after sowing, (Mondo et al., 2014).

\section{Seedling emergence (SE) and emergence speed index (ESI)}

Four replications of 50 seeds per lot, were uniformly distributed in plastic boxes $(52 \times 31 \times 10 \mathrm{~cm})$ filled with sand moistened to $70 \%$ of its water holding capacity, and maintained at room temperature $\left(\sim 25{ }^{\circ} \mathrm{C}\right)$. The emerged seedlings were counted daily until the 14th day after sowing. Emerged seedling was considered anyone with at least $2-\mathrm{cm}$ plumule emerged from the substrate. The results were expressed as percentage of emerged seedlings, and the seedling emergence index (Maguire, 1962) was calculated as: $\mathrm{SEI}=\Sigma(\mathrm{Et} / \mathrm{Dt})$, where Et is the number of newly emerged seedlings on the $t^{\text {th }}$ day and $D t$ is number of days after sowing.

\section{Field trials}

The field experiments were carried out at Fazenda Capivara, Embrapa Rice and Beans, located in Santo Antônio de Goiás, GO, $16^{\circ} 28^{\prime} 00$ " S and $49^{\circ} 17^{\prime} 00$ " W and $823 \mathrm{~m}$ of altitude. The climate is tropical savanna and considered Aw in the Köppen classification. There is one well-defined, normally dry season from May to September (autumn/winter) and one rainy season from October to April (spring/summer). The average temperature and total rainfall during the 2013/2014 cropping season was $29.6{ }^{\circ} \mathrm{C}$ and $1000 \mathrm{~mm}$ and in 2014/2015, $27.8^{\circ} \mathrm{C}$ and $1000 \mathrm{~mm}$, respectively.
The soil is classified as a clay loam (kaolinitic and thermic Typic Haplorthox) acidic soil. Before the trials deployment in October 2013 and October 2014, chemical analyses were performed at a depth of $0-0.20 \mathrm{~m}$ (Table 1). The experimental area has been cultivated in a no-tillage system for three consecutive years, and soybean (Glycine $\max$ L.) was the previous crop. A sprinkler irrigation system by center pivot was used, and three crop coefficients $(\mathrm{Kc})$ were divided into four periods between emergence and harvesting to manage the application of water. In the vegetative stage, a Kc value of 0.4 was used. For the reproductive phase, two values of $\mathrm{Kc}$ were used: 0.7 to 1.0 in the initial phase and the reverse of these values in the final phase of maturation, i.e., 1.0 to 0.7 . Therefore, the control of irrigation, respective to the depth of root system exploitation at $0.2 \mathrm{~m}$, was initiated with the available water capacity (AWC) at its maximum and successively subtracting the value of crop evapotranspiration until the total water reached the minimum limit of $40 \%$ of AWC (Doorenbos and Pruitt, 1976).

\section{Experimental design and treatments}

Two experiments were carried out independently, one for each variety 'BRSGO Serra Dourada' and 'BRS Esmeralda', in the same experimental area for two consecutive growing seasons (2013/14 and 2014/15). The experimental design was a randomized complete block in split plot scheme, with six replications. The seed lots of each cultivar were placed in the plots, and the priming protocols in the subplots. The priming protocol repeated the tested, zero, as the reference, $16 \mathrm{~h}$ and $22 \mathrm{~h}$ of priming duration. Subplots were $1.75 \mathrm{~m}$ (five rice rows) $\mathrm{x} 5 \mathrm{~m}$. The usable area was the three central rows, disregarding $0.50 \mathrm{~m}$ on each extremity.

\section{Crop management}

The upland rice seeds were sown on December $10^{\text {th }}, 2013$ and December $8^{\text {th }}, 2014$. The average emergence of rice seedling occurred at five days after sowing. The row spacing was $0.35 \mathrm{~m}$ and the seeding rate was 80 viable seeds per meter. The fertilizers were applied based on soil analysis (Sousa and Lobato, 2003), being applied at sowing $110 \mathrm{~kg} \mathrm{ha}$ ${ }^{1}$ of $\mathrm{P}_{2} \mathrm{O}_{5}$ as triple superphosphate and $20 \mathrm{~kg} \mathrm{ha}^{-1}$ of $\mathrm{N}$ as urea, supplemented by additional $60 \mathrm{~kg} \mathrm{ha}^{-1}$ of $\mathrm{N}$ as urea at topdressing, 20 days after emergence. Potassium was not needed. Cultural practices were performed according to standard recommendations for the rice crop in order to keep the area free from weeds, diseases and insects.

\section{Field evaluations}

In order to assess the time of flowering, the plots were observed daily. Full flowering date was considered when $50 \%$ of the plants of the subplot had panicle exposed and releasing pollen. The date was transformed into number of growing-degree-days (GDD), from sowing to full flowering, using the formula GDD = average daily temperature - basal temperature (McMaster and Wilhelm, 1997). The basal temperature was $10{ }^{\circ} \mathrm{C}$ (Gao et al., 1992). Additionally, subplots were evaluated to: number of panicles $\mathrm{m}^{-2}$ ,determined by counting the number of panicles within $1.0 \mathrm{~m}$ of one row in the useful area of each plot; number of grains per panicle, determined by counting the total number of grains in the panicles within $1.0 \mathrm{~m}$ of one row in the useful area of each plot; mass of 1000 grains, evaluated randomly by collecting and weighing two samples of 100 grains from each plot, corrected to $13 \%$ of water content; and grain yield, 
determined by weighing the harvested grain of each plot, corrected to $13 \%$ of water content and converted to $\mathrm{kg} \mathrm{ha}^{-1}$.

\section{Statistical analysis}

Data from laboratory trials, for each variety and seed lot, were submitted to analysis of variance as a completely randomized design, and in case of significance $(p \leq 0.05)$, those data were analyzed graphically. Raw data from field trials, such as number of degree-days, grain yield and production components were submitted to analysis of variance, and in case of significance $(\mathrm{p} \leq 0.05)$, the data were analyzed by means comparison using Tukey test (5\%) and or regression analysis.

\section{Conclusion}

As a conclusion, the effects of priming rice seeds were confirmed to be uniquely associated to the seeds physiological potential, including germination and vigor, which can result in benefits to the faster establishment and uniform stand in the field. However, those benefits did not extend beyond the early stages of crop development and were not observed on flowering and grain yield.

\section{Acknowledgment}

To the National Council for Scientific and Technological Development $(\mathrm{CNPq})$ for the financial support (Process 482320/2012-5 "Técnicas agronômicas para a sincronia de florescimento e elevação da alogamia na produção de sementes de arroz híbrido (Oryza sativa L.)".

\section{References}

Abdulrahmani B, Ghassemi-Golezani K, Valizadeh M, FeiziAsl V (2007) Seed priming and seedling establishment of barley (Hordeum vulgare L.). J Food Agric Environ. 5:179-184.

Akhter M, Sabar M, Zahid MA, Ahamd M (2007) Hybrid rice research and developments in Pakistan. Asian J Plant Sci. 6:795-801

Arif M, Jan MT, Marwat KB, Khan MA (2008) Seed priming improves emergence and yield of soybean. Pakistan J Bot. 40:1169-1177.

Ashraf M, Bray CM (1993) DNA synthesis in osmoprimed leek (Allium porrum L.) seeds and evidence for repair and replication. Seed Sci Res. 3:15-23.

Ashraf M, Foolad MR (2005) Pre-sowing seed treatment - a shotgun approach to improve germination, plant growth, and crop yield under saline and non-saline conditions. Adv Agron. 88:223-271

Azooz MM (2009) Salt stress mitigation by seed priming with salicylic acid in two faba bean genotypes differing in salt tolerance. Int J Agric Bio. 11:343-350.

Bajehbaj AA (2010) The effects of $\mathrm{NaCl}$ priming on salt tolerance in sunflower germination and seedling grown under salinity conditions. Afr J Biotechnol. 9:1764-1770.

Basra SMA, Zia MM, Mehmood T, Afzal I, Khaliq A (2002) Comparision of different invigoration techniques in wheat (Triticumaestivum L.) seeds. Pakistan J Arid Agric. 5: 11-16.

Basra SMA, Farooq M, Khaliq A (2003) Comparative study of pre-sowing seed enhancement treatments in fine rice (Oryza sativa L.). Pakistan J Life Sci. 1:5-9.

Basra SMA, Farooq M, Tabassum R, Ahmed N (2004) Osmohardening: A new technique for rice seed invigoration. Int Rice Res Notes. 27:74-75.

Basra SMA, Farooq M, Tabassum R (2005) Physiological and biochemical aspects of seed vigor enhancement treatments in fine rice (Oryza sativa L.). Seed Sci Technol. 33:623-628.
Bewley JD, Black M (1982) Physiology and biochemistry of seeds in relation to germination, $2^{\text {nd }}$ edn. Springer-Verlag, New York.

Bradford KJ (1986) Manipulation of seed water relations via osmotic priming to improve germination under stress conditions. HortScience. 21:1105-1112.

Bradford KJ, Steiner JJ, Trawatha SE (1990) Seed priming influence on germination and emergence of pepper seed lots. Crop Sci.30:718-721.

Brasil(2009)Rules for seed analysis. Ministry of Agriculture, Livestock and Food Supply. MAPA/ACS, Brasília.

Bray CM, Davison PA, Ashraf M, Taylor RM (1989) Biochemical changes during osmopriming of leek seeds. Ann Bot London. 63:185-193.

Brocklehurst PA, Dearman J (2008) Interaction between seed priming treatments and nine seed lots of carrot, celery and onion II. Seedling emergence and plant growth. Ann Appl Biol. 102:583-593.

Caprong I, Corbineau F, Dacher F, Job C, Côme D, Job D (2000) Sugar beet seed priming: effects of priming conditions on germination, solubilization of 11-S globulin and accumulation of LEA proteins. Seed Sci Res. 10:243-254.

Chen CC, Sung JM (2001) Priming bitter gourd seeds with selenium solution enhances germinability and antioxidative responses under sub-optimal temperature. Physiol Plantarum. 111:9-16.

Chen K, Arora R (2013) Priming memory invokes seed stresstolerance. Environ Exp Bot. 94:33-45.

Demir I, Okc G (2004) Aerated hydration treatment for improved germination and seedling growth in aubergine (Solanum melongena) and pepper (Cарsicum апnиит). Ann Appl Biol. 144:121-123.

Doorenbos J, Pruitt WO (1976) Las necesidades de agua de los cultivos. FAO, Roma.

Farooq M, Basra SMA, Karim HA, Afzal I (2004) Optimization of seed hardening techniques for rice seed envigoration. Emirates J Food Agric. 16:48-57.

Farooq M, Basra SMA, Hafeez K, Ahmad N (2005) Thermal hardening: a new seed vigor enhancement tool in rice. J Integr Plant Biol. 47:187-193.

Farooq M, Barsa SMA, Wahid A (2006a) Priming of field-sown rice seed enhances germination, seedling establishment, allometry and yield. Plant Growth Regul. 29:285-294.

Farooq M, Basra S, Tabassum R, Afzal I (2006b) Enhancing the performance of direct seeded fine rice by seed priming. Plant Prod Sci. 9:446-456.

Farooq M, Basra SMA, Afzal I, Khaliq A (2006c) Optimization of hydropriming techniques for rice seed invigoration. Seed Sci Technol. 34:507-512.

Farooq M, Basra SMA, Afzal I, Khaliq A (2006d) Seed invigoration by osmohardening in coarse and fine rice. Seed Sci Technol. 34:181-187.

Farooq M, Basra SMA, Tabassum R, Ahmed N (2006e) Evaluation of seed vigour enhancement techniques on physiological and biochemical basis in coarse rice (Oryza sativa L.). Seed Sci Technol. 34:741-750.

Farooq M, Basra SMA, Hussain M, Rehman H, Saleem BA (2007) Incorporation of polyamines in the priming media enhances the germination and early seedling growth in hybrid sunflower (Helianthus annuus L.). Int J Agric Biol. 9:868-872.

Farooq M, Basra SMA, Rehman H, Hussain M (2008a) Seed priming with polyamines improves the germination and early seedling growth in fine rice. J New Seeds. 9:145-155.

Farooq M, Basra SMA, Asad SA (2008b) Comparison of conventional puddling and dry tillage rice-wheat system. Paddy Water Environ. 6:397-404.

Farooq M, Basra SMA, Wahid A, Khaliq A, Kobayashi N (2009) Rice seed invigoration: a review. In: Lichtfouse E (ed) Organic farming, pest control and remediation of soil pollutants: sustainable agricultural reviews. Springer Science, Amsterdam. 
Farooq M, Siddique KHM, Rehman H, Aziz T, Lee DJ, Wahid A (2011) Rice direct seeding: Experiences, challenges and opportunities. Soil Till Res. 111:87-98.

Foti R, Abureni K, Tigere A, Gotosa J, Gere J (2008) The efficacy of different seed priming osmotica on the establishment of maize (Zea mays L.) caryopses. J Arid Environ. 72:1127-1130.

Frett JJ, Pill WG (1989) Germination characteristics of osmotically primed and stored impatiens seeds. SciHortic Amsterdam. 40:171-179.

Fujikura Y, Karssen CM (1995) Molecular studies on osmoprimed seeds of cauliflower: a partial amino acid sequence of a vigor-related protein and osmopriming-enhanced expression of putative aspartic protease. Seed Sci Res. 5:177181.

Gao L, Jin Z, Huang Y, Zhang L (1992) Rice clock model: a computer model to simulate rice development. Agr Forest Meteorol. 60:1-16.

Ghassemi-Golezani K, Sheikhzadeh-Mosaddegh P, Valizadeh M (2008) Effects of hydropriming duration and limited irrigation on field performance of chickpea. Res J Seed Sci. 1:34-40.

Gomes-Junior FG, Mondo VHV, Cicero SM, McDonald MB, Bennett MA (2009) Evaluation of priming effects on sweet corn seeds by SVIS. Seed Technol J. 31:95-100.

GRiSP (Global Rice Science Partnership) (2013) Rice almanac, 4th edn. International Rice Research Institute, Los Baños.

Harris D, Tripathi RS, Joshi A (2002) On-farm seed priming to improve crop establishment and yield in dry direct-seeded rice. In: Pandey S, Mortimer M, Wade L, Tuong TP, Lopez K, Hardy B (eds) Direct Seeding: Research Issues and Opportunities, Proceedings of the International Workshop on Direct Seeding in Asian Rice Systems: Strategic Research Issues and Opportunities, Bangkok, Thailand. Los Baños, 2000.

Heydecker W, Higgins J, Gulliver RL (1973) Accelerated germination by osmotic seed treatment. Nature. 246:42-44.

Hussain M, Farooq M, Basra SMA, Ahmad N (2006) Influence of seed priming techniques on the seedling establishment, yield and quality of hybrid sunflower. Int J Agric Biol. 8:14-18.

Hussain S, Zheng M, Khan F, Khaliq A, Fahad S, Peng S, Huang J, Cui K, Nie L (2015) Benefits of rice seed priming are offset permanently by prolonged storage and the storage conditions. Sci Rep. 5:1-12.

Jafar MZ, Farooq M, Cheema MA, Afzal I, Basra MA, Wahid MA, Aziz T, Shahid M (2012) Improving the performance of wheat by seed priming under saline conditions. J Agr Crop Sci. 198:28-45

Jianhua Z, McDonald MB (1997) The saturated salt accelerated aging test for small-seeded crops. Seed Sci Technol. 25:123131.

Kaur S, Gupta AK, Kaur N (2005) Seed priming increases crop yield possibly by modulating enzymes of sucrose metabolism in chickpea. J Agr Crop Sci. 191:81-87.

Khaliq A, Aslam F, Matloob A, Hussain S, Geng M, Wahid A, Rehman H (2015) Seed priming with selenium: Consequences for Emergence, Seedling Growth and Biochemical Attributes of Rice. Biol Trace Elem Res. 166:236-244.

Lee SS, Kim JH, Yun SH (1998) Effect of humidification and hardening treatment on seed germination of rice. Korean $\mathbf{J}$ Crop Sci. 43:157-160.

Maguire JD (1962) Speed of germination aid in selection and evaluation for seedling emergence and vigor. Crop Sci. 2:176177.

Marcos-Filho J (2005) Fisiologia de sementes de plantas cultivadas. Piracicaba, Fealq.

McDonald MB (1999) Seed deterioration: physiology, repair and assessment. Seed Sci Technol. 27:177-237.

Mcmaster GS, Wilhelm WW (1997) Growing degree-days: one equation, two interpretations. Agr Forest Meteorol. 87:291300 .
Mohanasarida K, Mathew J (2005) Effect of seed hardening on growth, yield and yield attributes of semi-dry rice (Oryza sativa L.). Res Crops. 6:26-28.

Mondo VHV, Gomes-Júnior FG, Cicero SM, Bennett MA, McDonald MB (2013) Priming protocols on Lactuca sativa seeds evaluated by image analysis. Agrarian. 6:402-409.

Mondo VHV, Costa-Neto CA, Costa MTM, Nascente AS, Lacerda MC (2014) Seed size does not affect germination or seed vigor of common bean. Seed Technol J. 36:81-88.

Nascente AS, Crusciol CAC, Cobucci T (2013) The no-tillage system and cover crops Alternatives to increase upland rice yields. Eur J Agron. 45:124-131.

Prasad R (2011) Aerobic rice systems. Adv Agron. 111:207-236.

Pill WG, Finch-Savage WE (1988) Effects of combining priming and plant growth regulator treatments on the synchronization of carrot seed germination. Ann Appl Biol. 113:383-389.

QinJ, Impa SM, Tang Q, Yang S, Yang J, Tao Y, Jagadish KSV (2013) Integrated nutrient, water and other agronomic options to enhance rice grain yield and $\mathrm{N}$ use efficiency in doubleseason rice crop. Field Crop Res. 148:15-23.

Rehman H, Basra SMA, Farooq M (2011) Field appraisal of seed priming to improve the growth, yield, and quality of direct seeded rice. Turkish J Agr For. 35:357-365.

Rehman H, Nawaz MQ, Basra SMA, Afzal I, Yasmeen A, UlHassan F (2014) Seed priming influence on early crop growth, phenological development and yield performance of Linola (Linumusitatissimum L.). J Integr Agric. 13:990-996.

Rehman A, Farooq M, Ahmad R, Basra SMA (2015) Seed priming with zinc improves the germination and early seedling growth of wheat. Seed SciTechnol. 43:262-268.

Rehman H, Nawaz MQ, Basra SMA, Afzal I, Farooq M, Wakeel A, Ning W (2015) Seed priming improves early seedling vigor, growth and productivity of spring maize. J Integr Agric. 14:1745-1754.

Roqueiro G, Maldonado SR, Ríos MC, Maroder H (2012) Fluctuations of oxidative stress indicators in Salix nigra seeds during priming. JExp Bot. 63:3631-3642.

Silva CB, Marcos-Filho J, Jourdan P, Bennett MA (2015) Performance of bell pepper seeds in response to drum priming with addition of 24-epibrassinolide. HortScience. 50:873-878.

Sliwinska E, Bassel GW, Bewley JD (2009) Germination of Arabidopsis thaliana seeds is not completed as a result of elongation of the radicle but of the adjacent transition zone and lower hypocotyls. J Exp Bot. 60:3587-3594.

Sousa DMG, Lobato E (2003) Adubação fosfatada em solos da região do Cerrado. Potafos, Piracicaba.

Subedi KD, Ma BL (2005) Seed Priming Does Not Improve Corn Yield in a Humid Temperate. Environ Agr J. 97:211-218.

Valdes VM, Bradford KJ, Mayberry KS (1985) Alleviation of thermodormancy in coated lettuce seeds by seed priming. HortScience.20:1112-1114

Varier A, VariAK, Dadlani M (2010) The subcellular basis of seed priming. Current Sci. 99:450-456.

WARDA (2002) In: Participatory Varietal Selection: Beyond the Flame. Jones, M.P. Wopereis, Pura (eds.), West Africa Rice Development Association (WARDA), Bouake, Cote d'Ivoire.

Wiebe HJ, Muhyaddin T (1987) Improvement of emergence by osmotic seed treatments in soils of high salinity. Acta Hort.198:91-100. 